\title{
Comparative Effect of Pethidine, Trichloroethylene, and Entonox on Fetal and Neonatal Acid-Base and $\mathrm{Po}_{2}$
}

\author{
T. J. PHILLIPS, R. R. MACDONALD
}

British Medical fournal, 1971, 3, 558-560

\section{Summary}

The second stage of labour is associated with relative fetal hypoxia and progressive metabolic acidosis. Maternal analgesia can increase the danger, especially for the high-risk fetus.

In 152 patients the effect on the fetus of pethidine alone, pethidine + trichloroethylene, or pethidine + Entonox was assessed by fetal scalp blood sampling. Fetal $\mathrm{pH}, \mathrm{PCO}_{2}$, and $\mathrm{Po}_{2}$ were measured and base excess was calculated. Capillary samples were also taken 45 to 60 minutes after birth in 88 of the babies to estimate the rate of neonatal recovery.

Entonox proved safer than trichloroethylene, and babies treated with it maintained their $\mathrm{Po}_{2}$ before birth, had better Apgar scores at birth, and one hour later were significantly less acidotic and much better oxygenated.

\section{Introduction}

The most critical time for fetal oxygenation is during the second stage of labour. The interval between contractions is short and even healthy babies are commonly born with low or negligible $\mathrm{Po}_{2}$. Especially for those babies at extra risk because of placental insufficiency, it is important to avoid any additional factor which might reduce oxygenation and increase fetal acidosis still further.

Some analgesia is required by most women in labour, and the analgesics most commonly used are pethidine, trichloroethylene, and premixed $50 \%$ nitrous oxide and $50 \%$ oxygen (Entonox). This study was designed to assess the effect of these analgesics on fetal acid-base and $\mathrm{Po}_{2}$ during the normal management of second stage labour.

\footnotetext{
Methods

Selection of Patients.-Patients in whom the fetus was considered to be at extra risk of intrapartum hypoxia during labour were selected for study. The criteria for selection were: primigravidae aged 35 and over, multigravidae aged 40 and over, previous stillbirth due to intrauterine hypoxia, pregnancy prolonged beyond 41 weeks, maternal diabetes, pre-eclampsia, threatened abortion or antepartum haemorrhage during the current pregnancy, small-for-dates fetus, or low urinary oestrogen excretion.

Analgesia.-In all the 152 patients studied intrasmuscular pethidine was used as the analgesic agent during the first stage, with an average total dose per patient of $200 \mathrm{mg}$. Fifty-one patients required no additional analgesia and 101 were randomly divided-51 were given trichloroethylene during the late first stage and throughout the second stage of labour and 50 were given Entonox. The three groups given pethidine alone,

Department of Obstetrics and Gynaecology, University of Leeds, Leeds LS2 9NG

T. I. PHILLIPS, M.B., M.R.C.o.G., Research Assistant

R. R. MACDONALD, M.D., F.R.C.o.G., Senior Lecturer
}

pethidine + trichloroethylene, or pethidine + Entonox proved in retrospect to have an even distribution of age, parity, and obstetric complications.

Collection of Samples.-Arterialized fetal scalp blood was obtained towards the end of the first stage of labour. Trichloroethylene or Entonox when required was then started and a second scalp sample was taken in each case 35 to 55 minutes later, during the second stage. Each fetal sample was collected anaerobically in heparinized nylon tubes by the method described by Saling (1965) as modified by Macdonald and Kelman (1967). Each sample was sealed, immediately placed in melting ice, and kept at a temperature of $0-4^{\circ} \mathrm{C}$ until analysis, which was usually 35 to 55 minutes later. In order to assess the rate of neonatal recovery a further sample of arterialized capillary blood was taken from 88 of the babies 45 to 60 minutes after birth. It was collected from the heel in heparinized glass capillary tubes. These 88 babies were randomly selected from the three analgesic groups.

Methods of Acid-base and $\mathrm{PO}_{2}$ Estimation.-Blood pH, $\mathrm{PCO}_{2}$, and base excess were determined according to the equilibration method of Astrup, Andersen, Engel, and Jorgensen (1960) by means of an Astrup microapparatus (Radiometer AME 1) and the nomogram devised by Andersen and Engel (1960). Partial pressure of oxygen was determined with a Radiometer Clark type polarographic microelectrode. All the blood gas analyses were carried out personally (by T.J.P.) to ensure uniformity.

\section{Results}

The four main groups of data are set out in Tables I-IV. In the analysis, individual results from three cases (two $\mathrm{pH}$ figures, one $\mathrm{PCO}_{2}$ result and one $\mathrm{Po}_{2}$ result) have been omitted as they failed to conform to a "normal" distribution and were regarded as freak readings due to error in measurement.

Fetal $p H .-$ The three groups started with almost identical average $\mathrm{pH}$ levels (Table I). When the second samples were taken 35 to 55 minutes later the $\mathrm{pH}$ had dropped in all three groups, but by four times as much in the trichloroethylene as compared with the Entonox group.

Fetal $\mathrm{PCO}_{2}$. - $\mathrm{PCO}_{2}$ dropped during treatment with Entonox, but rose significantly with the other two, and much more with trichloroethylene (Table II). The means of the three groups initially were significantly different from one another, but this did not affect the overall conclusion.

Fetal Base Deficit.-In Table III the initial populations were significantly different-that is, not randomly chosen. There was no difference in the ages of the patients, length of labour, or type of case. The explanation may be that the patients in the more acidotic pethidine group were already more heavily sedated and hence did not require further analgesia. This does not, however, affect the observation that the base deficit increased significantly more in the trichloroethylene and pethidine groups.

Fetal $\mathrm{PO}_{2}$.-Table IV shows again that the initial populations were not randomly scattered, but, as before, the more favourable group-that is, the better oxygenated group-was given trichloroethylene. Both the trichloroethylene and pethidine groups had large and significant falls in $\mathrm{Po}_{2}$ greater with trichloroethylene. The Entonox group not only maintained the $\mathrm{PO}_{2}$ level, but slightly, though not significantly, raised it. 
TABLE I-pH in "arterialized" fetal scalp blood before and after maternal inhalation of Trichloroethylene or Entonox. In the "control" pethidine group inhalational analgesia was not given

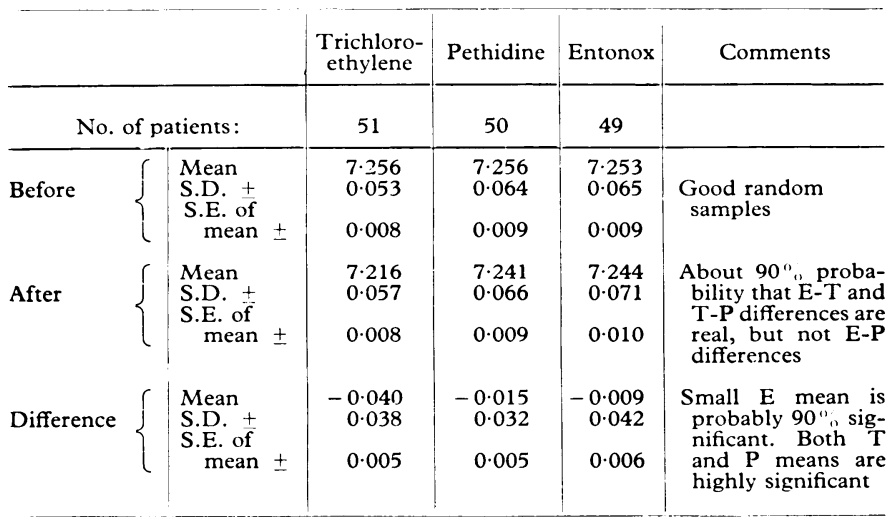

TABLE II-PCO, in fetal scalp blood before and after maternal inhalation of Trichloroethylene or Entonox

\begin{tabular}{|c|c|c|c|c|c|}
\hline & & $\begin{array}{l}\text { Trichloro- } \\
\text { ethylene }\end{array}$ & Pethidine & Entonox & Comments \\
\hline \multicolumn{2}{|c|}{ No. of patients: } & 51 & 51 & 49 & \\
\hline Before & $\begin{array}{l}\text { Mean } \\
\text { S.D. } \pm \\
\text { S.E. o } \\
\text { mean } \pm\end{array}$ & $\begin{array}{r}34 \cdot 9 \\
5 \cdot 9 \\
0 \cdot 8\end{array}$ & $\begin{array}{r}39 \cdot 8 \\
6 \cdot 1 \\
0 \cdot 9\end{array}$ & $\begin{array}{c}37 \cdot 0 \\
8 \cdot 1 \\
1 \cdot 15\end{array}$ & $\begin{array}{l}\text { Populations are sig- } \\
\text { nificantly different } \\
\begin{array}{l}\text { i.e., not ran- } \\
\text { domly selected } \\
\text { groups }\end{array}\end{array}$ \\
\hline After & $\begin{array}{l}\text { Mean } \\
\text { S.D. } t \\
\text { S.E. of } \\
\text { mean } \pm\end{array}$ & $\begin{array}{r}41 \cdot 3 \\
7 \cdot 7 \\
1 \cdot 1\end{array}$ & $\begin{array}{r}41 \cdot 8 \\
4 \cdot 8 \\
0 \cdot 7\end{array}$ & $\begin{array}{r}35 \cdot 0 \\
7 \cdot 0 \\
1 \cdot 0\end{array}$ & $\begin{array}{l}\text { E mean is signifi- } \\
\text { cantly lower than } \\
\text { the other two }\end{array}$ \\
\hline Difference & $\begin{array}{l}\text { Mean } \\
\text { S.D. } t \\
\text { S.E. of } \\
\text { mean } \pm\end{array}$ & $\begin{array}{r}+6.4 \\
6.5 \\
0.9\end{array}$ & $\begin{array}{r}+2.0 \\
4.8 \\
0.7\end{array}$ & $\begin{array}{r}-2 \cdot 0 \\
7 \cdot 9 \\
1 \cdot 1\end{array}$ & $\begin{array}{l}\text { All differences are } \\
\text { real (E and } \mathbf{P} \text { at } \\
95^{\prime \prime} \text {,). All three } \\
\text { differ siznificantly } \\
\text { from each other }\end{array}$ \\
\hline
\end{tabular}

TABLE III-Base deficit in fetal scalp blood before and after maternal inhalation of Trichloroethylene or Entonox

\begin{tabular}{|c|c|c|c|c|c|}
\hline & & $\begin{array}{l}\text { Trichloro- } \\
\text { ethylene }\end{array}$ & Pethidine & Entonox & Comments \\
\hline \multicolumn{2}{|c|}{ No. of patients: } & 51 & 51 & 50 & \\
\hline Before & $\begin{array}{l}\text { Mean } \\
\text { S.D. } t \\
\text { S.E. of } \\
\text { mean } \pm\end{array}$ & $\begin{array}{r}-8 \cdot 6 \\
2 \cdot 2 \\
0 \cdot 3\end{array}$ & $\begin{array}{r}-10 \cdot 2 \\
2 \cdot 1 \\
0 \cdot 3\end{array}$ & $\begin{array}{r}-9.3 \\
3.7 \\
0.5\end{array}$ & $\begin{array}{l}\text { Not randomly selec- } \\
\text { ted groups }\end{array}$ \\
\hline After & $\begin{array}{l}\text { Mean } \\
\text { S.D. } \pm \\
\text { S.E. of } \\
\text { mean } \pm\end{array}$ & $\begin{array}{r}-10.7 \\
1.6 \\
0.25\end{array}$ & $\begin{array}{r}-11.6 \\
1.9 \\
0.3\end{array}$ & $\begin{array}{r}-9 \cdot 7 \\
2.4 \\
0.3\end{array}$ & $\begin{array}{l}\text { E mean is signifi- } \\
\text { cantly lower than } \\
\text { the other two }\end{array}$ \\
\hline Difference & $\begin{array}{l}\text { Mean } \\
\text { S.D. } \pm \\
\text { S.E. of } \\
\text { mean } \pm\end{array}$ & $\begin{array}{r}+2.1 \\
2.0 \\
0.3\end{array}$ & $\begin{array}{r}+1.3 \\
1.7 \\
0.25\end{array}$ & $\begin{array}{r}+0.4 \\
2.6 \\
0.4\end{array}$ & $\begin{array}{l}\text { E difference not } \\
\text { significant; the } \\
\text { other two are sig- } \\
\text { nificant. E mean } \\
\text { differs significantly } \\
\text { from other two }\end{array}$ \\
\hline
\end{tabular}

TABLE IV- $\mathrm{PO}_{2}(\mathrm{~mm} \mathrm{Hg})$ in fetal scalp blood before and after maternal inhalation of Trichloroethylene or Entonox

\begin{tabular}{|c|c|c|c|c|c|}
\hline & & $\begin{array}{l}\text { Trichloro- } \\
\text { ethylene }\end{array}$ & Pethidine & Entonox & Comments \\
\hline \multicolumn{2}{|c|}{ No. of patients: } & 51 & 50 & 50 & \\
\hline Before & $\begin{array}{l}\text { Mean } \\
\text { S.D. } \pm \\
\text { S.E. of } \\
\text { mean } \pm\end{array}$ & $\begin{array}{r}30 \cdot 0 \\
5 \cdot 8 \\
0 \cdot 8\end{array}$ & $\begin{array}{r}26 \cdot 1 \\
6 \cdot 5 \\
0 \cdot 9\end{array}$ & $\begin{array}{r}27 \cdot 8 \\
4.6 \\
0.65\end{array}$ & $\begin{array}{l}\text { Borderline signifi- } \\
\text { cant differences in } \\
\text { populations }\end{array}$ \\
\hline After & $\begin{array}{l}\text { Mean } \\
\text { S.D. } t \\
\text { S.E. of } \\
\text { mean } \pm\end{array}$ & $\begin{array}{r}24 \cdot 6 \\
4 \cdot 0 \\
0 \cdot 6\end{array}$ & $\begin{array}{r}22 \cdot 7 \\
5 \cdot 7 \\
0 \cdot 8\end{array}$ & $\begin{array}{r}28 \cdot 7 \\
6 \cdot 2 \\
0 \cdot 9\end{array}$ & $\begin{array}{l}\text { E mean significantly } \\
\text { higher than } T \text { and } \\
P\end{array}$ \\
\hline Difference & $\begin{array}{l}\text { Mean } \\
\text { S.D. } t \\
\text { S.E. of } \\
\text { mean } \pm\end{array}$ & $\begin{array}{r}-5.4 \\
0.5 \\
0.5\end{array}$ & $\begin{array}{r}-3.4 \\
4.3 \\
0.6\end{array}$ & $\begin{array}{c}+0 \cdot 9 \\
4.7 \\
0.65\end{array}$ & $\begin{array}{l}\mathrm{E} \text { mean is signifi- } \\
\text { cantly different } \\
\text { from } \mathrm{T} \text { and } \mathrm{P} \text {. } \\
\mathrm{T} \text { and } \mathbf{P} \text { possibly } \\
\text { differ }(95 \% \text { level })\end{array}$ \\
\hline
\end{tabular}

TABLE V-Apgar scores at birth after maternal analgesia with pethidine alone, pethidine plus Trichloroethylene, or pethidine plus Entonox (151 babies)

\begin{tabular}{|c|c|c|c|c|c|c|}
\hline \multirow{2}{*}{$\begin{array}{l}\text { Apgar } \\
\text { Score }\end{array}$} & \multicolumn{3}{|c|}{ At 1 Minute } & \multicolumn{3}{|c|}{ At 5 Minutes } \\
\hline & $\begin{array}{l}\text { Trichloro- } \\
\text { ethylene }\end{array}$ & Pethidine & Entonox & $\begin{array}{l}\text { Trichloro- } \\
\text { ethylene }\end{array}$ & Pethidine & Entonox \\
\hline $\begin{array}{r}4 \\
5 \\
6 \\
7 \\
8 \\
9 \\
10\end{array}$ & $\begin{array}{r}9 \\
1 \\
27 \\
14 \\
-\end{array}$ & $\frac{\frac{3}{27}}{\frac{21}{-}}$ & $\begin{array}{r}\bar{Z} \\
\frac{21}{20} \\
5 \\
4\end{array}$ & $\frac{\overline{5}}{\frac{5}{30}}$ & $\begin{array}{r}- \\
1 \\
1 \\
18 \\
15 \\
16\end{array}$ & $\begin{array}{r}\bar{Z} \\
\bar{Z} \\
19 \\
29 \\
29\end{array}$ \\
\hline $\begin{array}{c}\text { Average } \\
\text { Score }\end{array}$ & $6 \cdot 17$ & $6 \cdot 70$ & $7 \cdot 42$ & 8.43 & $8 \cdot 85$ & $9 \cdot 20$ \\
\hline
\end{tabular}

TABLE VI-Fetal and neonatal capillary blood. Effect of maternal analgesia on $p H$, base excess, and $\mathrm{Po}_{\mathrm{O}}$

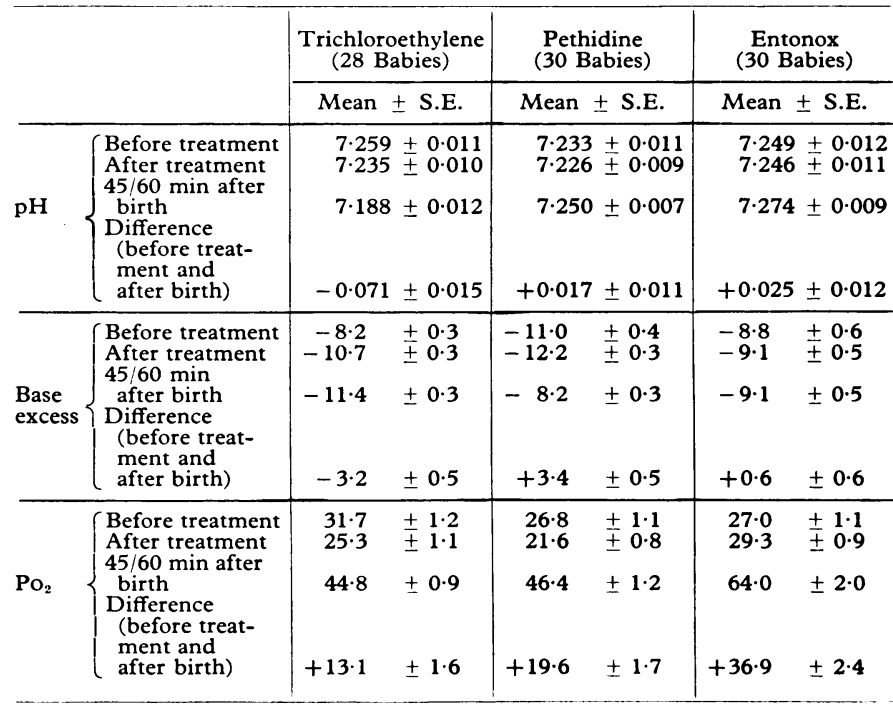
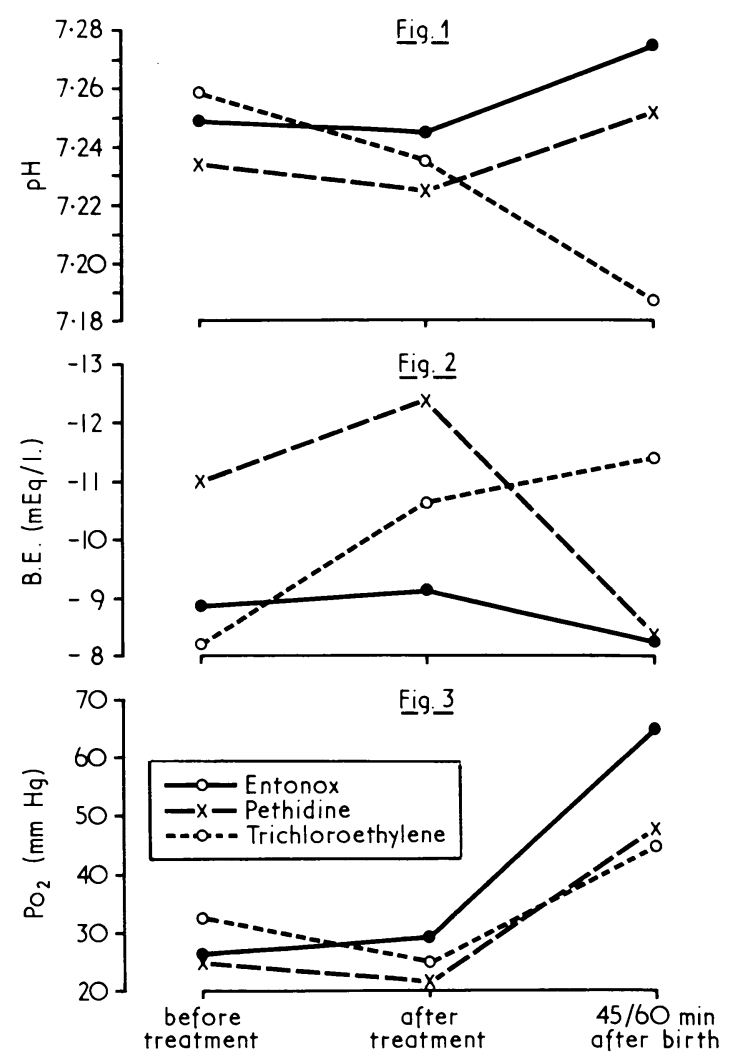

FIG. 1-Fetal and neonatal capillary blood. Effect of maternal analgesia on pH ( 88 babies). FIG. 2 -Fetal and neonatal capillary blood. Effect of blood. Effect of maternal analgesia on $\mathrm{Po}_{2}$. 
Apgar Data.-Apgar scores (Table V) are perhaps more liable to observer error, but the absence of Apgar 4 and the higher number of Apgar 10 with Entonox are highly significant. These data show the apparent beneficial effect of Entonox.

Neonatal Capillary Blood.-Eighty-eight babies had a further arterialized blood sample collected 45 to 60 minutes after birth. There were 28 from the Entonox group, 30 from the trichloroethylene group, and 30 from the pethidine group. $\mathrm{pH}$, base excess, and $\mathrm{Po}_{2}$ were assessed, and the means and standard error of the means were calculated for the results before and after treatment and after birth (Table VI). While $\mathrm{pH}$ improved after birth in the pethidine and Entonox groups (Fig. 1), there was a serious fall in $\mathrm{pH}$ after birth in the babies whose mothers had been given trichloroethylene. The base deficit was reduced after birth in the pethidine and Entonox groups, but continued to increase in the trichloroethylene group (Fig. 2). In the pethidine and trichloroethylene groups $\mathrm{Po}_{2}$ fell during treatment but rose after birth (Fig. 3). By contrast $\mathrm{Po}_{2}$ in the Entonox group was maintained during treatment and improved significantly more in the first hour after birth.

\section{Discussion}

The first perinatal mortality survey (Butler and Bonham, 1963) showed that asphyxia during labour was the commonest cause of stillbirth. Placental reserve is reduced, particularly in the elderly primigravidae, in postmaturity, pre-eclampsia, accidental haemorrhage, and in the notoriously vulnerable small-for-dates baby.

During the normal second stage the fetal $\mathrm{pH}$ falls gradually, the base deficit continues to increase and there is a progressive fall in $\mathrm{PO}_{2}$ (Saling, 1968). "Intensive care" of the mother and fetus during labour, with close personal and electronic supervision, helps to reduce the risk of sudden and unexpected fetal death from hypoxia and acidosis, but the need for analgesic drugs introduces a further adverse factor. Most mothers require one or more injections of pethidine during the first stage and may also need some analgesic inhalation towards the end of the first stage and during the second stage.

Nitrous oxide and air analgesia originally introduced by Minitt (1934) was found under some circumstances to lead to a serious fall in maternal oxygenation, and gas and air has now been superseded by the mixture in one cylinder of $50 \%$ nitrous oxide and $50 \%$ oxygen (Entonox). In a multihospital trial organized by the Medical Research Council (1970) $90 \%$ of the mothers using nitrous oxide and oxygen mixtures found the gas helpful; nearly three-quarters of the mothers stated that the degree of analgesia was complete or considerable and $84 \%$ were satisfied with the relief obtained.

Our results suggest that the normal progressive acidosis and hypoxia during the second stage is significantly aggravated by maternal analgesia with trichloroethylene. Fetal $\mathrm{pH}$ fell, base deficit increased, and $\mathrm{Po}_{2}$ fell much more than in the "control" group given pethidine alone. By contrast, maternal analgesia with Entonox was associated with less acidosis and hypoxia than in the group using only pethidine, with less increase in the base deficit and no reduction in the mean $\mathrm{Po}_{2}$. When the trichloroethylene and Entonox groups were compared, the fall in $\mathrm{pH}$, increase in base deficit, and fall in $\mathrm{PO}_{2}$ was four or more times greater with trichloroethylene.

Oxygen enriched mixtures are believed to be helpful for the fetus at extra risk, especially during preparation for operative delivery because of fetal distress (Chamberlain, 1970). In our study fetal $\mathrm{PO}_{2}$ actually rose during the second stage in more than half the fetuses whose mothers were breathing Entonox.

The implication is that Entonox is not only less harmful than trichloroethylene, but that it actually improves oxygenation during a critical phase while at the same time providing the mother with adequate pain relief. The difference in Apgar scores between the trichloroethylene and Entonox groups is highly significant.

The superiority of Entonox is further shown by the rate of neonatal recovery (Figs. 1-3). Those babies whose mothers breathed Entonox achieved within an hour of birth a significantly higher $\mathrm{pH}$, a greater reduction in base deficit, and a higher $\mathrm{Po}_{2}$. Subsequent mental development may sometimes depend on the speed and degree of recovery from acidosis and hypoxia.

Our conclusion was that Entonox is safer than trichloroethylene, but has postive benefits. At birth, the Entonox babies had better Apgar scores and one hour after birth they were significantly less acidotic and much better oxygenated.

This study was made possible by an I.C.I. Research Fellowship, a Research Fellowship from the Royal College of Obstetricians and Gynaecologists, and by a generous grant from the British Oxygen Company. For the statistical analysis we are indebted to Mr. A. D. Hewitt of B.O.C. We are also grateful to Professor J. S. Scott for advice and encouragement, and to the nursing staff of the Leeds Maternity Hospital for their help.

\section{References}

Andersen, S. O., and Engel, K. (1960). Scandinavian fournal of Clinical and Laboratory Investigation, 12, 177.

Astrup, P., Andersen, S. O., Engel, K., and Jorgensen, K. (1960). Scandinavian fournal of Clinical and Laboratory Investigation, 12, 172.

Butler, N. R., and Bonham, D. G. (1963). Perinatal Mortality. Edinburgh, Livingstone.

Chamberlain, G. (1970). British fournai of Hospital Medicine, 3, 556.

Macdonald, R. R., and Kelman, G. R. (1967). Fournal of Obstetrics and Gynaecology of the British Commonwealth, 74, 826.

Medical Research Council Committee on Nitrous Oxide and Oxygen Analgesia in Midwifery (1970). British Medical fournal, 1, 709.

Minitt, R. J. (1934). Lancet, 1, 1278.

Saling, E. (1965). Fournal of the International Federation of Gynaecology and Obstetrics, 3, 100 .

Saling, E. (1968). Foetal and Neonatal Hypoxia, translated by F. E. Loeffler, p. 32. London, Arnold. 